\title{
"The Bead of Raw Sweat in a Field of Dainty Perspirers": Nationalism, Whiteness and the Olympic-Class Ordeal of Tonya Harding
}

\author{
Elizabeth L. Krause
}

\begin{abstract}
This paper examines the interrelations of whiteness, gender, class and nationalism as represented in popular media discourses surrounding the coverage of the assault on Olympic ice skater Nancy Kerrigan and the investigation of her rival, Tonya Harding. As with other recent works that have refocused the issue of "race" on whiteness, this essay seeks to unveil the exclusionary social processes in which boundaries are set and marked within the "difference" of whiteness. The concepts of habitus and historicity are used to understand how Tonya Harding became marked as "white trash," and the implications of her "flawed" qualifications are explored. Furthermore, this paper identifies ongoing ideological struggles over moral regulation and reproduction of the nation and its subjects.
\end{abstract}

Keywords: Nationalism, whiteness, gender, class, race, ideology, media discourse.

\section{PRELUde}

Seven years ago, as a reporter on the education beat at the Eugene Register-Guard, I was sent to an elementary school to cover the visit of an Oregon up-and-coming Olympic hopeful: Tonya Harding. I had told the editors of my own background as a figure skater-getting up before sunrise, arriving weary-eyed at the misty-cold skating rink, tracing figureeights on the frosted ice, then practicing axels, lutzes, salchows, double loops, waltz jumps, sit spins, and laybacks. Figuring that I might hold the secret knowledge to translate the mysteries of this sport into a comprehensible story, my editors assigned me to meet the 17-year-old athlete. At the time, Tonya seemed like an ordinary teenager, perhaps deceivingly shy and innocent. Her short blond hair framed her prim and pointy features. She wore a turtleneck sweater and sat cross-legged in a chair with her hands neatly placed on her lap as she spoke to a roomful of eager grade-schoolers. My interview, monitored by a health insurance representative whose company had "adopted" her, led me to write a benign feature story. A sports editor wrote the fairytale-like headline, "Oregon's Ice Princess Thrills Youngsters." 
In 1987, seven years before she would represent the United States at the winter Olympics in Norway, Harding was unmarked by the reputation that would come to haunt her-a reputation as a low-class, halterwearing white chick who grew up on the "wrong" side of town and who associated with questionable men. To wit, her ex-husband, Jeff Gillooly, was found guilty of racketeering in connection with the attack on Nancy Kerrigan at a January 6, 1994 practice session. In what the press described as an "anticlimactic" ending to a "10-week whodunit," Tonya on March 16, 1994, pleaded guilty to conspiring to hinder prosecution of the case (Janofsky 1994). The hearing did not include the extent of her knowledge of the attack itself; she maintained she only learned about her ex-husband's involvement after she returned to Oregon from Detroit, where she won the U.S. National Figure Skating competition. As New York Times columnist George Vecsey (1994b) wrote:

We're never going to know if Tonya Harding really sat in with those four cretins and planned the most famous knee-whacking in American history.

What we can know, however, and what may be more important for understanding why Icegate became "the biggest story" in sportswriter history-memory, is what was at stake in this social drama: the ongoing ideological struggles over moral regulation and reproduction of the nation and its subjects.

\section{WHITENESS AND NATIONALISM}

This paper examines the relationship between whiteness and nationalism as it came to be represented primarily in popular media discourses surrounding "Icegate." Whiteness is a particular type of ethnicity in ways not immediately obvious, perhaps because "whiteness" is not typically thought of as ethnicity. Yet racial identities, as Coco Fusco has pointed out, "are not only black, Latino, Asian, Native American, and so on; they are also white. To ignore white ethnicity is to redouble its hegemony by naturalizing it" (quoted in hooks 1990:171). To critically evaluate how "the other" is constructed, she suggests, requires that white ethnicity be specifically addressed.

As with other recent works that have refocused the issue of "race" on whiteness ${ }^{1}$, it is my hope to unveil the exclusionary social processes in which boundaries are set and marked within the "difference" of whiteness-the most "obscure" of all "because it is not considered a difference" (Levine 1994).

The illusory practices in which whiteness gets away with being unmarked, and as such an alleged category of sameness, are rendered suddenly transparent when we examine the people who have been placed 
on the "borders of whiteness" (Frankenberg 1993:224). Whiteness becomes a problematic category when a particular marked type of whiteness, in this case "white trash," threatens to make the category heterogeneous and hence contaminate its imagined purity ${ }^{2}$. The marking and racializing of Tonya Harding (e.g., being called a "trailer nigger") in talk and media representations illustrates how the unmarked category of "whiteness" is very much imbued with class ideology, one which portrays a group whose virtue flows from a fitness to consume certain products in certain ways. The ideology of late capitalism "assumes the equality of all participants in the market," according to Eric Wolf, and the "distinction between classes" is converted "into distinctions of virtue and merit. Success is demonstrated by the ability to acquire valued commodities; hence, inability to consume signals social defeat" (1982:390).

With increasing blatancy, the media exploited stereotypes of Tonya's white trashiness. I believe this exploitation was a way to place Tonya Harding at the outer fringes of whiteness, at its "borders" (Frankenberg 1993). The "right" kinds of whites don't do that; they don't get involved with people who would stoop so low as to bash an opponent's knee. Marking Tonya as flawed, as "trashy," placed her outside the bounds of proper whiteness. It distanced Tonya from respectable working-class, pull-yourself-up-by-your-bootstraps "folk" hero(in)-es like Nancy. The effect was to reaffirm the superiority of whites as a "race." Sportswriters who called "Icegate" the "biggest story we've ever covered," but had "no clue" as to why (Kirkpatrick 1994), failed to see the historicity implicit in the coverage.

Historicity is a useful concept for understanding what motivations lay beneath the coverage. It refers to how a society sees itself, and how this self-perception reproduces society based on moral warrants. Historicity occurs at that moment when society looks itself in the mirror and says, "This is the kind of place we are; this behavior is not of this place." This metasocial commentary is clearly oriented to the past, and how a society views its continuity with that past, even though the past may very well be "a foreign country," in that it will be remarkably different from the present. What keeps the past from feeling alien is the way it has consciously been appropriated to inform behaviors and relations in the present. In other words, the past is made to feel familiar because of the way in which a society objectifies history and orients the past to the present in a manner of its own liking. That is, the "we" conceives of itself, as a matter of the past-present relation (Touraine 1977:18-19). ${ }^{3}$ With Icegate, for example, Tonya wasn't of "us," where the "us" was the corpus of mostly white, and mostly male, sports reporters. Characteristics attached to Tonya Harding made her expendable, like so much unrecyclable household trash. ${ }^{4}$ 
Tonya's habitus, her "tackiness," her "white trashiness," placed her outside the bounds of being "really" white. Tonya was racialized in large part because her embodied micro-behaviors did not conform to the dominant Anglo-ideology of what sorts of bodily form an Olympic figure skater, and as such a representative of the nation, was supposed to display. In this arena, ideologies of class, race and gender became deeply embedded in a politics of cultural struggle related to sensibilities central to nationalism. Consider the unfitness, the raunchiness, of Tonya as represented in the New York Times just ten days after the attack:

Even before the Kerrigan affair, it was a little hard to imagine the tough-talking, scrappy Miss Harding picking up endorsements from, say, Clairol or Wheaties. Fairly or otherwise-Miss Harding has not been charged with any wrongdoing-the events of the past several days probably make even a chainsaw endorsement a fairly remote possibility (Grimes 1994, emphasis added).

As compared with the fitness, the purity, of Nancy:

For her many fans, Miss Kerrigan was already a new Dorothy Hamill in the making. Now she's Snow White (ibid.).

In one moment Nancy was a virtuous character from a fairytale; in the next, she would become a national heroine. By February 4, she had been transformed into "Boston's own," a wholesome yet vulnerable Irish lass, evoking in Bostonians the memory of another of their fallen heroes:

By being whacked on the knee, by crying in pain, she has subliminally reminded Boston people of, yes, their slain Irish prince, John Fitzgerald Kennedy, who never got to perform the triple axels everybody knew were in him. But by surviving with a certain girlish grace that cannot be totally taught, even by the wizards of Pro-Serv, Nancy Kerrigan has also reminded people of, yes, the woman who carried on when the Boston Irish prince was murdered, Jacqueline Bouvier Kennedy Onassis (Vecsey 1994).

Bringing the Kennedys into the Icegate drama evokes Camelot and a mythic past. Clearly, more than "objective" reporting was at work in the above quotation. An elaborate discourse of nationalism, race, class and gender seemed to be unfolding in the press reports. When news broke nationwide in early 1994 that Tonya's ex-husband was suspected of conspiring to have Nancy Kerrigan's leg bashed, and that Tonya too might have been involved in planning the assault, I became obsessed with the story. I became obsessed firstly because of having met her and because of having skated at the Clackamas ice-rink-in-a-mall that later became her practice home, and secondly because I suspected that more 
was being fought out in this story than the future careers of two figure skaters.

During the weeks that followed the January 6 attack, as media coverage became incessant, friends complained about the ink and airtime being "wasted" on this "trivial" issue when there were many important stories to be covered. Why did the media not tire of this story? Was an ideological war being waged in this story of the dark side to the fairytale sport of figure skating - a sport whose mythical quality is perhaps exaggerated through the infrequency of coverage on the networks or in the newspapers? The appetite for "Tonyagate" seemed insatiable. What was at stake in these descriptions that painted in broad binary strokes the stark contrast between good and evil? Is it possible that through such a "mundane" and "everyday" site such as an Olympic figure skating scandal we can enter the ideology of nationalism?

I propose that the ideological struggles concerning the perpetuity of the nation-state are ongoing, and that "Icegate" was indicative of such a struggle. Nationalist struggles infiltrate the everyday. When played out in the form of social dramas, such struggles help people to take sides in how to "imagine" the community of the nation-state (see Anderson 1983); this act of imagining, of reifying, keeps the nation-state afloat. The vast territory dubbed the United States can hence be perceived and possibly even experienced (at least in given moments) as a unified entity, a nation-state. The ideological struggles of nationalism are simultaneously cultural and political struggles, and the cultural politics of Icegate make it ripe for analysis.

\section{IDEOLOGY, OLYMPICS AND TONYA'S QUEER QUALIFICATIONS}

The Olympic Games provide an arena for nation-building and myth-making. The opening ceremony of the 1994 Winter Olympics featured a parade of nations in which the essence of each nation was displayed through symbols and costumes. Norwegian officials saw the Olympics as an opportunity to "put Norway on the world map" (Puijk 1994). Norwegian publicity efforts sought to showcase Norwegian culture and to show how Norwegians relate to nature. The focus on nature combined with the emphasis on folk tales and mythology was an attempt to construct a pristine moment, critical for the project of nation-building. ${ }^{5}$ The pristine moment helps to legitimate that which springs from it, e.g. Nordic civility. As a young nation that became independent from Sweden only in the early 1900s, for example, Norway has an interest in nation-building (Puijk 1994). But even relatively old nations, such as the United States, have an ongoing interest in nation-building, though we might better refer to this ongoing interest as one of continually reproducing the nation. 
The Olympic myth, like the national myth, is founded on a pristine moment, one that relies on the presumed fairness of clean sporting wherein the virtues of youth, strength and fearlessness are asserted. The Olympic torch speaks to the ideal of fairness, to the spirit of gaming. Its glow perhaps temporarily burns from popular memory the unfair, advantage that characterizes a world in which capitalistic relations of domination and subordination prevail. One writer likened the Olympics to "a national patriotic day for the whole world, a day when flags wave and people march and the grim realities of the past and, often, the present, are forgotten in a global surge of pride and unity" (Henry 1994:50).

When sporting is peaceful and clean, as the ideology of sport dictates, the myth can work its wonders. It can help the world forget its troubles, help it imagine itself as a healthy community, and help it deny the pathology that its inclusions and exclusions breed. What better place to provide the world with "respite from the ordeals of daily headlines and household heartbreak" (Henry 1994) than women's figure skating, a sport that has always been the "grand finale" of the winter games? Known as a glamorous sport, it supplies the "durable stuff of fantasy" (Duffy 1994a:53). As the New York Times reported:

More than any other sports figures, ice skaters seem to lead a fairy tale existence. For them, the laws of gravity do not apply. Their art lies in concealing effort, so the audience does not see the sweat, or hear any unseemly grunting. They are, in a way, figures of fiction, their unreality heightened by stage costumes (Grimes 1994).

Sport has long been a domain "keyed" by a "dominant kind of masculinity," i.e., white, heterosexual, male (Corrigan 1991:273). As in music, where the key sets limits on the possible notes that can be played, this masculine key has made statements about "acceptable forms and images of social activity" (Corrigan and Sayer 1991:6). For much of the twentieth century, sport has been a place where masculinity could be tested and proved. Tests of manhood occurred against a backdrop of sports values, "honoring boundaries, playing by the rules, working together for a common goal, submitting to authority," argues Robert Lipsyte, writing in the New York Times Magazine (Lipsyte 1995:51). When the Western frontier closed in 1890, he suggests that "there was no place left for American men to transform themselves into the stalwarts who would keep democracy alive and lead the country to global greatness...so sport became the new frontier." The idea was that sport would create "a better formed race." And although that "race" was "supposed to be white, and of Anglo-Saxon origin, it was the immigrant waves that filled the ball parks." Whether playing them, watching them, or talking about them, sports were "the quickest ticket to becoming an American" (Lipsyte 1995:54). 
Sports have had a difficult time maintaining their virtuous image, in part because of the high monetary stakes but also because of changing practices of reportage. Ballplayers of the 1950s were more accessible to fans, as they lived in the same middle-class neighborhoods. Furthermore, sportswriters of that era, covering baseball greats such as Babe Ruth and Mickey Mantle, played down the seamy side of the players' lives. This was required, "lest they lose their free meals and tickets, and access-it was the ball clubs who picked up the train fares while scribes and athletes rode together, played cards together, winked together at each others' manly peccadilloes" (Lipsyte 1995:52). The recent past has witnessed a crisis of the sports hero; or as Lipsyte puts it, "those manly virtues of self-discipline, responsibility, altruism and dedication seem to have been deleted from the athletic contract with America"(Lipsyte 1995:52).

Crisis of the sports hero aside, there are still certain qualifications that sports heroes are expected to possess, and these qualifications (spoken or unspoken) allow us a peek into an ideology in which class, gender, ethnicity and nationalism intersect. The double-standard with regard to male and female athletes' sexual practices speaks to the way in which gender ideologies in society at large are reflected in discourses about star athletes. "While boy Babes can sleep with as many women as they can fit around their home and road schedules, girl Babes' sex lives are far more circumscribed," according to Lipsyte. Any female athlete who slept with as many partners as some male athletes have boasted "would be considered a slut not a league leader" (Lipsyte 1995:54). The sportswriters and broader media undeniably played on the image of Tonya as slut. The media reached a low point when the sensational "news" show Hard Copy, during an interview with Jeff Gillooly, showed a home video of the former couple's wedding night that featured Tonyathe-bride doing a strip-tease for her groom.

The media's questioning of whether Tonya Harding was qualified to represent the United States as a world-class figure skater suggests that not just anybody qualifies for this sport of glamour, in which not only stamina and strength are important, but also grace. Dominant judgments about who qualifies for particular roles and is capable of carrying them out are integral to the concept of ideology and how individuals are made into subjects, i.e., subjects of the nation-state. As Göran Therborn points out, ideologies "subject and qualify subjects" in three important senses: ideologies make people recognize what exists and hence become conscious of their sense of identity and of what is real in the world; they enable people to determine what is good and hence to understand what is within the norms; and they give people a sense of what is possible, and thus a sense of limits as well as the consequences of transcending those limits (Therborn 1980:18; see also Althusser 1969, Foucault 1982). 
Tonya Harding has had a hard time fitting the bill of qualifications in terms of stamina as well as grace. She suffers from asthma, and the "experts" say she lacks the "natural" elegance of figure skating greats such as Peggy Fleming, Dorothy Hamill, or Katarina Witt. Her strength is what has carried her to the arena of national and world contests, and this alone was not enough to qualify her to become America's sweetheart on ice. Nancy and Tonya were differentially qualified for this prerequisite. Nancy could remind her fellow Bostonians of Jackie Kennedy "by surviving with a certain girlish grace that cannot be totally taught" (Vecsey 1994, emphasis added). The way Tonya Harding inhabited her social space ensured that she was virtually unqualified to ever possess such grace.

The media began questioning Tonya's qualifications as the "right" kind of person/woman/girl for the genteel sport of figure skating several years ago. In 1991 she was described as "wearing the crown without the glitz," and known for stunning with the triple axel (Janofsky 1991, NYT 1991). By fall 1993 she had become "hard-luck Harding" as opposed to "right stuff" Kerrigan (Bondy 1993, Longman 1993). ${ }^{6}$ Her qualifications were further questioned with a history of equipment failures, the most famous being the broken lace at the Olympics. Between early January when Nancy was attacked, and mid-January, when Tonya's exhusband became a suspect in plotting the attack, the media descriptions increasingly cast doubt on Tonya as having the "right stuff" for figure skating. However, Peggy Fleming and Dick Button's enthusiastic commentary for television viewers of the U.S. Figure Skating Championships, at which time Tonya was not yet suspected of any involvement, provide a remarkable contrast to later descriptions:

Fleming: She can be powerful, intimidating and vulnerable all at the same time.

Button: These are magnificent jumps that she's doing.

Fleming: It's her height and speed that is so different from all the other women...Pretty movements.

Button: She's a very mature skater. You can see her taking the time to execute these deep edges and this flowing movement. (U.S. Figure Skating Championships, Detroit, 1994)

By January 24, when questions circulated about how much Tonya knew about the plot to "maim" her rival, Time put their assessment of Tonya's qualifications in blunt terms:

Tonya Harding is not-nor has she ever been-like most skaters. She is neither politic nor polished, sociable nor sophisticated. Instead, she is the bead of raw sweat in a field of dainty perspirers; the asthmatic who heaves uncontrollably while others pant prettily; the pool-playing, drag-racing, trash-talking bad girl of a sport that thrives on illusion and 
politesse. When rivals fairly float through their programs, she's the skater who best bullies gravity. She fights it off like a mugger; stroking the ice hard, pushing it away the same way she brushes off fans who pester her for autographs (Smolowe 1994:51).

This excerpt "makes sense" because it indexes and semiotically contextualizes a particular prediscursive world in which there already exists classificatory schemes. By prediscursive, I am referring to the idea that linguistic signs can only be uttered in a world that is already filled with meaning. "All knowledge at a given cognitive or historical moment must be about something with which the knower is already acquainted to some degree and in some respect" (Parmentier 1994:3). As Bakhtin (1984) reminds with regard to discourse, all utterances come with social history.

By classificatory schemes, I am referring to those schemes that are generated through practices embedded in what Bourdieu calls the universes of habitus ${ }^{7}$, resulting from internalizations of the social world and its material conditions. These internalizations get converted into a disposition, i.e., a way of being, and in turn this disposition generates practices and perceptions-ways of consuming, of making "objectively classifiable judgments" about what should be done when and where, of dividing the social world into classificatory schemes, based on economic logic (easy, cheap, convenient logic) (Bourdieu 1984:170).

Bourdieu identifies three primary realms of consumption in which the dominant class asserts its superior distinction: food, culture and presentation. The ways of treating, caring for, feeding and maintaining the body reveal the deepest dispositions of the habitus. The body is, after all, a "sign-bearing" and "sign-wearing" social product-"the only tangible manifestation of the 'person' " (Bourdieu 1984:190-192). For this reason, the seemingly small tokens of behavior-e.g., Tonya's "bead of raw sweat in a field of dainty perspirers," as Smolowe described to her Time readers-form the basis by which the social world becomes divided.

We may recall that "taste classifies, and it classifies the classifier," as Bourdieu has instructed (1984:6), so that social subjects' class positions are ultimately revealed through the distinctions they make. In their everyday modes of consumption, they will invariably reveal a tendency toward a taste for necessity (where any slab of meat will do) or a necessity for taste (where only the finest filet mignon will suffice). And these distinctions are not the product so much of individual choice as they are of social conditioning, of previous generations inscribing themselves on young bodies in an "unconscious" way (Bourdieu 1984:70). Society can thus reproduce the social order without being conscious of how it is reproducing it, because social agents enact their dispositions without having to be fully aware of their enactment. A key notion in understanding how symbolic capital structures the social world is misrecognition. Our 
habitus-that "structuring structure" that constitutes the total ideological field (Bourdieu 1984:170-172) - blinds us from "the objective" truth:

The schemes of the habitus, the primary forms of classification, owe their specific efficacy to the fact that they function below the level of consciousness and language, beyond the reach of introspective scrutiny or control by the will. Orienting practices practically, they embed what some would mistakenly call values in the most automatic gestures or the apparently most insignificant techniques of the body-ways of walking or blowing one's nose, ways of eating or talking-and engage the most fundamental principles of construction and evaluation of the social world, those which most directly express the division of labour (between the classes, the age groups and the sexes)...(Bourdieu 1984:466).

The Kerrigan attack provided the media with an opportunity to say of Tonya what they had been thinking all along: She's out of place; she doesn't belong in this sport; she's not of us. This is where Therborn's notion of qualifications, Bourdieu's concept of habitus, and Touraine's model of historicity all collide. Tonya's out-of-placeness, as indexed by her "trashy" tastes and her questionable qualifications, matters because she cast doubt on the integrity of the games and muddied the global pristine moment, a moment marked by a "global surge of pride and unity." The foreign media saw the scandal as symptomatic of the degeneracy of American society in general (see Clarey 1994, Reid 1994). Tonya's being-in-the-world also matters because her flaws lend definition to America's - and the West's-image of itself: who we are as a people. The implication is that "we as a people" are homogenously egalitarian, individualistic and fair. The "free" field of sports competition dictates that each individual has equal access and equal opportunity. The sports game is analogous to the commodity game of free-market capitalism, where the message of egalitarianism is that those who work hard get ahead. ${ }^{8}$ Good American athletes behave like the speed-skater Bonnie Blair. They adhere to the "cult of 'fair play,' the code of play of those who have the self-control not to get so carried away by the game that they forget that it is "only a game'" (Bourdieu 1984:215). Mainstream media discourse, one which Teun van Dijk (1993) reminds constitutes elite discourse and hence ultimately serves to reproduce ideologies that further presuppositions and structures favoring the dominant class, depicted Tonya as deficient:

A different person could have fashioned from this autobiography an inspirational story of transcending poverty, but somehow Tonya's personality keeps getting in the way (Adler 1994:71). 
The focus on Tonya-the-individual denies the broader social context, yet such strategies are fundamental to egalitarian ideology, which in the United States historically was "reserved for whites and rejected the notion of class," (Saxton 1990:313). Egalitarianism is potentially destructive and dehumanizing through its logic of inclusions and exclusions, which are often fought out in popular culture and realized in nationalism (Kapferer 1988:14).

Tonya's out-of-placeness, then, relied on flaws that presumably led her to violate the cult of fair play; even her broken lace was framed as a violation. CBS commentator Scott Hamilton stated that the referees' granting her time to recover seemed "unfair to the rest of the skaters," and a New York Times Magazine photo of her crying to the judges with her skate lifted onto the sideboard featured the caption "Tonya Harding lost a lace at the 1994 Olympics. Her sense of fair play was already missing" (Lipsyte 1995:54). Over the course of the coverage, the media depicted her taste for necessity as tasteless. Her desire to win got the best of her, or at very least the best of those around her, and she wanted too much the chance to cash in on the riches that typically accompany an Olympic gold medalist. She violated a key mark of distinction. Athletes are supposed to hold to certain principles. The doxa at work was that she violated the code of good sportsmanship-if not directly, then by hanging out with slimeballs who carried out the dirty deed. What sane person would debate the immorality of clubbing an opponent to win? ${ }^{9}$

\section{Class Fractions, 'LADIES,' AND THE RACE OF 'WHITE TRASH'}

Kate Rounds, reflecting on figure skating for Ms. magazine, dismissed class as an important dimension to the coverage of the NancyTonya story, positing the "truth" of this sport to be "that you have to be a lady to gain access" (1994:27). In fact, Tonya did gain access. After all, let's not forget she was twice a national champion. What Tonya didn't gain, as Rounds acknowledges, was access to the payoff that is supposed to accompany world-class female figure skaters.

Even before the knee bashing and the creepily embarrassing bootlace incident at Lillehammer, she had no endorsements (Rounds 1994:31).

The point of endorsements is that they are part of the lure of ice skating. For young skaters who show talent, the Olympic dream becomes a path to realize the rags-to-riches journey, a journey at the core of American ideology. I agree with Rounds that figure skating at a local level attracts kids from the working-, but more often, middle-class strata of society. Were we to devise a spectrum to classify working-class vs. upper-class leisure sites, with bowling alleys on one end and country clubs on the other, ice skating rinks would definitely fall closer to the 
bowlers than golfers. But the "paradox" of ice skating is that it looks "classy" and so is seen as "elitist," as Rounds points out (1994:28). The other "paradox," in my estimate, is that more than a few people who participate in the sport take on the airs of the dominant class. To wit, Diane Rawlinson, Tonya's coach, travels in elite social circles in Portland, and her name frequently appears in elite gossip columns, according to a native Oregonian friend who closely followed the coverage of Harding. Rounds, however, maintains that just because many parents have to struggle financially to put their daughters and sons through the figureskating training regime, we can eliminate class from the analysis. With class thrown out, and I would argue naively so, Rounds can then posit feminine norms as what are "truly" being fought out.

A key point that Rounds misses is the way class figures into the construction of femininity. The notion of being "a lady" is rooted in bourgeois morality, a morality in which norms of the body and of sexual behavior were influenced by the proliferation of modern nationalisms in Europe (Parker et al. 1992:2). To posit gender as existing beyond the bounds of class is analogous to positing class as existing separate from the nation-state. Of course, class divisions and gender roles existed prior to the formation of nations, but nations have a way of playing on and reshaping these norms as part of the project of continual imagining of community. Each nation-state, as Connell has suggested, is "a bearer of gender" and as such has a "gender regime" as a major feature of its "internal organization" (Connell 1990).

Between the attack on Nancy Kerrigan in Detroit and her performance in Hamer (after which Kerrigan showed herself to be a poor loser, making snide remarks about Ukrainian gold medalist Oksana Baiul's emotionality), Nancy clearly was a bourgeois hero-in-the-making. Alexander Saxton suggests that "[ $t$ ] he construction of heroes is at the crux of the ideological process because fictional heroes act out, or realize, class relationships" (1990:321). Nancy symbolized everything "good" about being a good, middle-class WASP: fitting in, working hard, having good morals and refined manners, being unselfish, not standing out, not being showy, restraining emotion, seeking approval, and being part of a solid family (Robertiello and Hoguet 1987:38). After her Olympic performance, a commentator exclaimed, "Brenda and Daniel Kerrigan's daughter has seized the moment and made it her own!" and then, as Nancy was getting off the ice, added, "She's looking for her Mom and Dad."

Nancy's construction as a hero, however, needed to be set against a villain. Tonya increasingly became that villain. By March 7, Time came to describe her as "the grungy underdog whose ex-husband and entourage allegedly tried to knock off Kerrigan to establish their own proletarian ice queen-and money machine" (Duffy 1994b:63). 
The Kerrigans' ethnicity has become an attribute that makes them respectable. Harding did not have an ethnicity that could redeem her. She was an unhyphenated white, a category with "no clearcut identification" with a specific European origin (Lieberson 1985:159), open to the derogatory label of "white trash," even "trailer nigger"10. The term "Irish nigger" is not something much heard anymore, and although the Kerrigan family would not be described as "lace Irish," as were the Kennedys, neither would they be called "shanty Irish."

A reporter for The New Yorker seemed to be seeking the source of Tonya's flawed whiteness in an essay that was critical of stories that identified Portland as Tonya's home; "she comes from a place that's tougher and more intractable." The article described Clackamas County as an inorganic, mix-match of a geographical space whose settled areas look as though "they had emerged abruptly, hacked out of the tangle of blackberry bushes and firs." The piece focused on a meeting of the Tonya Harding Fan Club, which moved to a member's home after being told that someone else had reserved the room at the Clackamas mall rinkTonya likely being the only Olympic contender who "trains within sight of the Steak Escape, Let's Talk Turkey, Hot Dog on a Stick and Chick-fil$A^{\prime \prime}$ (Orlean 1994). The carefully chosen details of the story seemed to reinscribe, in a nuanced East-coast way, the habitus of whites who aren't quite white, whose tackiness somehow places them outside the bounds of being really white:

One of the other women said, "Have you ever seen Tonya's mother's trailer. It's just up the road here, and it is meticulous. It is lovely. It is tidy. You would never even know it's a trailer." "Trailer trash is what they call people out here," another woman said to me. She sat down and started tapping on the table with her fingernails. They were long and burgundy-colored, and each one had a different small image painted on it-a shooting star, a sun, a lightning bolt. She said, "There are plenty of people who think we're scum because we live out here on the east side. Well, I live in a very non-scum neighborhood. It's actually a so-called good neighborhood, but it's always going to be thought of as trash, because it's east side." She tapped. Her fingernails clicked: lightning bolt, star, sun (Orlean 1994:51).

Szwed's suggestion that "[t]hroughout history, we have been confusing cultural styles with race" (1975:25) is relevant here. Tonya was racialized in large part because her embodied micro-behaviors did not conform to the dominant Anglo-ideology of what sorts of bodily form a national-class figure skater was supposed to have. The media used economic logic to play on the doxic element of Tonya's "poor" sportsmanship, and then picked out the practices that marked her as not belonging 
to the world of figure skating, which is comprised of a genteel class-or at least a world that pretends to be genteel.

Bourdieu points our attention to the relation that different class fractions have to their bodies. Such a class-body relation is manifest in the sports each class chooses (1984:212). Class fractions occupy and create social spaces through life-styles founded on embodied practices. "The cognitive structures which social agents implement in their practical knowledge of the social world are internalized, 'embodied' social structures" (Bourdieu 1984:468). What Bourdieu forgets is that a class fraction, e.g. the working class, is not necessarily uniform. More than one habitus and form of cultural capital may be represented within the same class fraction as is evidenced with Nancy Kerrigan and Tonya Harding.

The Nancy-Tonya tale allows us to follow the lead of Gramsci (1971), and step back from an economic reductionist position, which assumes social conditions are set and that people operate within particular constraints, and instead look at how subjects are complexly constituted. On several occasions, when I suggested to friends that there was a class dimension to the Nancy-Tonya controversy, I was challenged. "But they're both from working-class families," they would say. It is true that Nancy and Tonya share a class position, but they represent separate fractions within the working-class. Within these fractions, important distinctions exist. Throughout the coverage, the binary oppositions outlined in Table 1 were played upon. The left side represents "illegitimate" ways of being, whereas the right side represents "legitimate," or doxic, ways of being.

\begin{tabular}{|l|l|}
\hline Illegitimate & Legitimate \\
\hline ill-mannered, impolite & mannered, polite \\
evil & good \\
immoral & moral \\
stupid & wise \\
wrong & right \\
trashy, sleazy & glamourous, classy \\
low-class & high-class \\
loose, whorish & virgin-like \\
wrong & right \\
lazy, undisciplined & hard-working, disciplined \\
guilty (?) & innocent (?) \\
at-the-bottom & above-it-all \\
aggressive & passive, not a pushover \\
animalistic, close to nature, & civilized, distant from nature, \\
subnational & upstanding citizen \\
rural/county-dweller, moves & urban-dweller, settled \\
around a lot & \\
\hline
\end{tabular}

Table 1: Binary Oppositions 
Both Nancy and Tonya, according to Adler (1994:71) had an "underprivileged childhood by the genteel standards of the skating world," but there were significant differences. Nancy's father was a welder,

but she was Gloria Vanderbilt next to Harding, the daughter of a night waitress and her fifth husband, an occasional laborer and truckdriver. Growing up in and around Portland, Harding never lived in one house very long, and spent part of one gloomy year in a 17 -foot trailer. Her father, Al, taught her to hunt and fish and fix up old cars and split wood for the stove-a skill she credits with developing the upperbody strength that is the secret to her successful jumping...She learned to shoot with a cut-down .22 before she could read, but she learned to skate before she could shoot. (Adler 1994)

Underlined in this passage are characteristics that contribute to Tonya's expendability; Anglo-Saxons are not supposed to possess these qualities. A similar expendable feature was, in the nineteenth century, attached to Irish-Americans. Their whiteness was suspect. In the years before the Civil War, adjectives such as "low-browed and savage, groveling and bestial, lazy and wild, simian and sensual" were used by many Americans to describe the Irish Catholic "race." As Roediger notes, "the striking similarity of this litany of insults to the list of traits ascribed to antebellum Blacks hardly requires comment" (Roediger 1991:133). Although the Irish had experiences similar to the Blacks-in terms of being discriminated against, living in slum conditions, working in unskilled exploitative conditions, and suffering from loneliness due to separation from their kinfolk and homeland-the shared oppression was no guarantee of solidarity or contempt. By 1843, however, Irish abolitionists were the minority. The majority of Irish came to insist on their whiteness and to embrace white supremacist politics. They found allies in the Catholic Church and the Democratic Party; the latter in particular provided a platform of "white unity and white entitlement" (Roediger, p. 140). Democrats since the 1830s had been constructing a political ideology of exclusion in which blacks were viewed as unfit for civic participation, an idea that "could be transmuted into the notion that all whites were so fit" (Roediger, p. 141). ${ }^{11}$ Irish politicians were known for refashioning the myth of Anglo-Saxon superiority to create a distinct "American race," said to be a "unique blend of all that was best in the white European races" (Horsman 1981:250-51). This history underscores the power of constructed classificatory systems in creating exclusions and inclusions.

The habitus of Nancy and Tonya became prototypes for virtuous working-class vs. trashy working-class. One columnist drew an analogy between Nancy, as Bill Clinton's polished, working-class-cum-aristocrat 
public persona, and Tonya, as the president's unsavory low-class private persona (Klein 1994:57). One need only consider how Nancy's and Tonya's different tastes were reflected in the media's depiction of their body forms, their choice of clothing and hobbies, and their different ways of talking, not to mention their sexual practices. ${ }^{12}$ The made-for-TV movie, "Tonya and Nancy: The Inside Story," (April 30, 1994) showed several scenes where Tonya was making out with her boyfriend/husband/ex-husband Jeff Gillooly. Nancy's love life was never an issue-until she began to fall from grace and the media began to look askance at stories that she was dating her 40 -year-old agent.

However, immediately following the attack, Tonya's off-the-rink activities became an issue in media coverage of Icegate. In a colored sidebar, Newsweek listed Tonya's hobbies as "drag-racing, auto repair and hunting," and as for Nancy, "She does charity work for the blind, Roller-blades and has recently taken up golf" (Adler 1994). Bourdieu notes that working-class people "choose sports that demand a high investment of energy, effort or even pain (e.g., boxing) and which sometimes endanger the body itself" (1984:213). Clearly, the contrast between Tonya's interest in the dangerous and high-thrill sport of drag-racing and Nancy's recent interest in the bourgeois sport of golf could not be greater. As a hero, Nancy represented the American faith in upward mobility and "real American values-family, discipline, self-reliance, niceness" (Pollitt 1994:297).

Their choice of clothing, both on and off the ice, similarly became a means of exposing Tonya's unfitness as a white. A photo of a halterwearing teenager, hands planted firmly on hips, long red fingernails, unbrushed old-permed hair blowing over splotchy sun-burned shoulders, bears a caption that reads, "Bratty: Harding never made it to charm school" (Adler 1994:71). In contrast, the caption to a photo of a wholesome-looking Kerrigan, donning a bright red jacket with an American flag on the sleeve, reads "Holding her head up" (Adler 1994:71) A similar photo from Time of the same week reads, "Pretty as Gold: Kerrigan, talking to the press last week, showed the natural elegance and smile that could be worth millions" (Smolowe 1994:54).

On the ice, Tonya's skating dress-the one most-often pictured in the media, anyway-was fashioned from bright purple fabric. Although the color purple has been associated with low-class as well as regal dress, the cut of Tonya's dress lent the color an association with the former. It was decorated with a dense array of gold sequins bordering a diamondshaped, flesh-colored section of fabric that cut widely across her breasts and down to her navel, while her muscular arms were accentuated by the outfit's sleeveless design. (One sportswriter claimed she was deducted several fractions of a point in Detroit for her costume, considered "skimpy, cheap" [Araton 1994:B8].) Whereas Tonya's costumes were said 
to be hand-sewn by her mother or by Tonya herself, Kerrigan's, valued at $\$ 5,000$, were donated by designer Vera Wang. The one mostphotographed bespoke of elegant evening wear; it was fashioned from a neutral, shimmering but subtle earth-tone gold fabric, had long-sleeves and rose high on the neck.

Much more could be written on the details of bodily form: Tonya's stomping her feet on the ice before she skates, her tough post-nationals victory gesture of biting teeth to lip and clenching her fists, her postperformance heaving caused by asthma, her failure to follow convention by not sitting down between her coaches as she waited for her marks, her sucking then spitting out a lozenge on-camera during an interview after her nationals win. All of these were written about or commented on in stereotypical fashion in the media as a way to use her habitus as evidence for how she was unqualified to represent the U.S. as a world-class "lady" figure skater. When Tonya's ice lace broke at the Olympics, an exasperated Scott Hamilton exclaimed, "I've never seen anything like this before at any competition...Things like this just don't happen."

\section{IMPLICATIONS FOR GENDER AND DOMESTICITY}

Several months after the attack, and to a greater extent a year afterward, the characteristics ascribed to Harding and Kerrigan were not so starkly opposed. Public sympathies for Harding grew because of a perception that the media had treated her badly. The alternative press criticized the mainstream media as "irresponsible" in its handling of Harding. Susan Douglas of the Progressive suggested that Harding was "used as a warning to other women and girls, especially those from 'the wrong side of the tracks.' It is a warning about knowing your caste and staying in it" (Douglas 1994:12). Through its coverage of the clubbing on Nancy Kerrigan, the media legitimized the barriers women face based on gender, class and ethnicity and heightened the social drama that followed the initial breach of norm-governed social relations, i.e., when associates of one Olympic skater conspired to injure her rival's knee.

Victor Turner's (1974) notion of the social drama, with its four phases-breach, mounting crisis, redressive action and reintegration-is useful for grasping how Icegate played out in the media and why the tables turned: how Kerrigan fell from ice-princess grace and Harding rose from trailer-park-slut infamy. By the time the crisis had mounted, clearly the breach was, as Turner predicted, "coextensive with some dominant cleavage" in the relevant social relations (Turner 1974:38). This phase is evidenced in the media treatment of Tonya as trashy, and as I showed above, this moment revealed the "true state of affairs" (Turner 1974:39), i.e., the dominant discourse about class, gender and ethnicity (here, white trash) and what sorts of qualifications an Olympic athlete 
ought to possess. This is exactly why the mainstream and conservative media could use the event to preach about the morality of athletes and the state of modern sporting. Meg Greenfield of Newsweek referenced the scandal as she commented on the "state of our peculiar contemporary moral universe" (1994:70). The National Review went so far as to claim that "manners are the outward signature of morals" (1994:21). Both commentators fail to recognize that manners also serve as the "small change of madness," or rather those small tokens of behavior that legitimize elite and dominant classes or groups (Williams 1989, and personal communication 1994; Bourdieu 1984).

Moral debates continued as the redressive action phase began in the form of formal juridical action involving the legal apparatus. Here is where Turner suggests "society is at its most 'self-conscious,", where the doxic morals are articulated. By the time Tonya plea-bargained to be found guilty of conspiring and was then forced to resign from the U.S. Figure Skating Association, the sympathy for her had increased. As for Kerrigan, the phase of reintegration of the normal social order had changed the structure of the social field and left her marked.

Kerrigan became trapped in a "no-win" situation. She was portrayed as a "goody-two-skates," and viewed as a poor loser at the Olympics when she was overheard criticizing gold medalist Oksana Baiul for taking so long to make her appearance for the award ceremonies. Told that Baiul was putting on makeup, Kerrigan quipped, "She's only going to cry again anyway." Kerrigan was later pegged as an "ingrate" when, while riding on a float in a Mickey Mouse parade at Disneyland, she remarked, "This is corny. This is so corny" (Berkow 1994:B11).

Yet through these blurrings of the demarcations between good and evil, crucial norms and relationships persisted. Were we to work this space further, we might consider how the nation often stands as a metaphor for kinship. As David Schneider pointed out more than twenty years ago, the "diffuse, enduring solidarity" that is supposed to exist among nationals rests on tropes of kinship, reproduction, "shared substance" and "codes for conduct" (Schneider 1969:120). The nation becomes analogous to an extended family. Part of the moral warrant for this family's members speaks to proper gender roles for women and men. The warrant is particularly important because like gender, "nationality is a relational term whose identity derives from its inheritance in a system of differences" (Parker et al. 1992:5). National identity is constructed largely in terms of contrasting what it is not from what it is (see Yuval-Davis 1989).

The figure-skating scandal illustrates that gender does not function exclusively in the realm of kinship but "is constructed as well in the economy and the polity" (Scott 1986:1068). What type of athlete is fit to receive endorsements is integral to the politics of the nation. Just as poli- 
tics constructs gender, so too does gender construct politics (Scott 1986:1070). Analyses of cultural struggles ought also to include the interplay between gender and states (Silverblatt 1991:158). Nation-making historically has played on essentialist notions of gender roles to legitimate rule (see Krause 1994).

Where the media explained why Tonya was not the right kind of white, they were also providing statements about how the "right" kind of white American middle-class female ought to be. Tonya became an "ordeal of civility" (see Cuddihy 1987). That Tonya's habitus fell outside the bounds of respectability represented a crisis of the category of female (see Garber 1992:125). The media coverage consisted of consciousnessreminding regarding an imagined homogenous nation, and hence amounted to a "passive revolution," due to the media's running metasocial commentary on proper behavior not only for middle-class Americans but for white, female middle-class Americans.

Women's figure skating has been said to be the most popular event of the winter Olympics. Unlike some sports, such as speed-skating and skiing, where male and female uniforms are virtually identical, figure skating has dramatically different dress codes for men and women. Furthermore, women skaters are called "ladies." Katha Pollitt, explaining why she was rooting for Tonya, argued that figure skating "is really a princess contest." She commended Tonya for challenging its princess norms.

When Oksana Baiul was awarded the gold, Time wrote that her victory was largely because "she flirted shamelessly with folks in the jury box" (Duffy 1994b:63). The implication is that she won on her good looks and her charm rather than her athletic or artistic ability. Would anyone have said that Aleksei Urmanov's gold medal resulted from flirtation?

If we accept the Olympic Games as a stage for nationalist myths to be enacted, we can see how the Nancy-Tonya saga became a particularly salient drama for the nation to assert its ideology concerning the legitimacy of the American upwardly mobile middle-class. Flux was at work. Gramsci, being a theorist of flux, focuses on the process by which the social order is taken for granted, and the strategies that may be used to challenge or reinforce what has become naturalized. Political struggle for Gramsci is integrated with cultural or hegemonic struggle. Gramsci's later writings posit hegemony as a total fusion of economic, political, intellectual and moral objectives, which a social group brings about "through the intermediary of ideology when an ideology manages to 'spread throughout the whole of society determining not only united economic and political objectives but also intellectual and moral unity" (Mouffe 1981:223; Gramsci 1971:180-5). Hegemonic struggles have everything to do with the dominant group's winning of consent. The subaltern population's granting of consent results because of the dominant 
group's prestige due to their "position and function in the world of production" (Gramsci 1971:12). Who, however, defends white trash?

Once won, though, popular consent cannot be taken for granted; hegemony "must be constantly and ceaselessly renewed, reenacted" (Hall 1988:54). This is why Nancy could not remain the Ice Queen. Her reputation and her manners tainted her. Hegemony is fragile-it is not "a finished and monolithic ideological formation" but rather "a problematic, contested, political process of domination and struggle" (Roseberry 1994:358).

Tonya became increasingly expendable, like an estranged daughter, as Nancy was embraced as a national heroine. The tables turned when Tonya became the underdog and Nancy the tainted princess. Nancy's imperfect manners meant she could no longer occupy the role of princess because she was not conforming to the moral order. Loyalties, in the case of the media, began shifting toward Tonya, as when last Christmas she was shown dressed as a Santa Claus, passing out goodies to the needy. She became the victim of society, the underdog who might be able to redeem herself and rise above her class habitus after all, thereby again reaffirming the ideology of American egalitarianism.

\section{ACKNOWLEDGMENTS}

I would like to thank Brackette Williams for her thoughtful input to an earlier version of this paper, originally written for her seminar "The Politics of Cultural Struggle," Spring 1994 at the University of Arizona. I would also like to recognize the thought-provoking discussions encouraged by Jane Hill in her seminar "Language and Racism," Fall 1994, as well as the stimulating conversations prompted by Ana Alonso in her seminar "Nationalism, Ethnicity, Gender, Sexuality: The Intimacy of Power," Spring 1995.

\section{ENDNOTES}

${ }^{1}$ See for example Frankenberg 1993, Hill 1994a, 1994b, Levine 1994, Roediger 1991.

${ }^{2}$ Williams (1989) discusses notions of homogeneity and heterogeneity in her essay on nationalism and ethnicity. See also her ethnography (1991).

${ }^{3}$ This interpretation of Touraine derives from lectures and discussions in Brackette Williams' seminar "The Politics of Cultural Struggle," Spring 1994, Department of Anthropology, University of Arizona.

${ }^{4}$ My thanks to Brackette Williams for suggesting this metaphor.

${ }^{5}$ Newman 1987, Horsman 1981, and McWhiney 1988 each provide examples of the construction of the pristine moment in English, American and Irish- 
American nationalism respectively. Williams 1993 discusses the notion of "prenationalist precepts" at length.

${ }^{6}$ A search of "Tonya Harding" in a database including articles indexed in The New York Times, The Washington Post, Los Angeles Times, The Christian Science Monitor, and The Wall Street Journal yielded 188 articles. Of those, five appeared in 1991, two in 1992, and two in 1993. The remaining 179 articles appeared in 1994. A search of "Nancy Kerrigan" yielded some of these plus an additional 85 articles.

${ }^{7}$ Antecedents to Bourdieu's ideas about habitus can be found in Gramsci 1971:354, who suggested in a discussion of tastes and food that "it is also true that 'man is what he eats', in so far as diet is one of the expressions of social relations taken as a whole, and every social group has its own basic form of diet. But one might equally well say that 'man is his clothing', 'man is his housing' or 'man is his particular way of reproducing himself, that is, his family'. For, together with diet, housing, clothing and reproduction are among the elements of social life in which social relations as a whole are manifested in the most evident and widespread (i.e., mass) fashion" (1979:354-355). Bourdieu also builds on Mauss, whose essay on "The notion of body techniques" underscores the importance of "the ways in which from society to society men know how to use their bodies" (1979:97). I find it odd that Bourdieu fails to build on what these earlier theorists had to say.

${ }^{8}$ Cf. Kapferer's (1988) discussion of Australian nationalism's ideology of egalitarianism.

${ }^{9}$ See Bourdieu 1977.

${ }^{10}$ I was told that Jesse Jackson said that we should give Tonya a break because people call her "a trailer nigger"; I was unable to find the newspaper article in which this statement allegedly appeared, but that the media will freely use the term "white trash" but largely censors terms such as "trailer nigger" shows the covert ways that expendable categories are created. In a related matter, but also anecdotal, an African-American student in John Calagione's class at the City College of New York said, "Tonya's as black as I am" (Daniel Nugent, personal communication 1994).

${ }^{11}$ The 1830s were the peak of so-called Jacksonian democracy, an ideology said to "champion greater rights for the common man" and as such, "aided by the strong spirit of equality among the people of the newer settlements in the South and West" (Hirsch 1988:245). This ideology of democracy, however, was waged at the expense of Indians, forcibly removed from their lands, and racism against Blacks. Horsman notes that Jackson was confident "the same Providence which had blessed the United States with good government, power and prosperity had provided that inferior peoples should yield their 'unused' domain to those who through its use could benefit themselves and the world" (Horsman 1981:202).

${ }^{12}$ Sexuality has long been a field in which whiteness has been waged: "Whiteness took shape against the corresponding counter-images, shunting anxieties and desires regarding relationships to nature and to sexuality onto Blacks" (Roediger 1991:151). 


\section{REFERENCES}

Adler, Jerry 1994 Thin Ice. Newsweek, January 24, pp. 69-73.

Althusser, Louis 1969 [1971] Ideology and Ideological State Apparatuses (Notes towards an Investigation), in Lenin and Philosophy, and other Essays, New Left Books.

Anderson, Benedict 1983 Imagined Communities: Reflections on the Origin and Spread of Nationalism. London: Verso.

Araton, Harvey 1994 No Taste of Victory in Harding. New York Times, February 23, p. B8.

Bakhtin, Mikhail 1984 Discourse in Dostoevsky. In Problems of Dostoevsky's Poetics, ed., Caryl Emerson, Theory and History of Literature, Vol. 8, pp. 181-269, Minneapolis: University of Minnesota Press.

Berkow, Ira 1994 Kerrigan is No Bambi. New York Times, March 8, 1994, B11.

Bondy, Filip 1993 Figure Skater with the Right Stuff, New York Times, January 23, p. 31.

Bourdieu, Pierre 1977 Outline of a Theory of Practice. Cambridge: Cambridge University Press.

-1984 Distinction: A Social Critique of the Judgement of Taste. Cambridge: Harvard University Press.

Clarey, Christopher 1994 Skating News Crosses the Atlantic, Too. New York Times, January 16, p. S5.

Connell, R.W. 1990 The State, Gender and Sexual Politics: Theory and Appraisal. Forthcoming in Theory and Society. Manuscript, $27 \mathrm{pp}$.

Corrigan, Philip 1991 Masculinity as Right: Some Thoughts on the Genealogy of "Rational Violence." In Social Forms, Human Capacities, pp. 269-288. New York and London: Routledge.

Corrigan, Philip, and Derek Sayer 1991[1985] The Great Arch: English State Formation as Cultural Revolution. London: Basil Blackwell.

Cuddihy, John Murray 1987 The Ordeal of Civility: Freud, Marx, Levi-Strauss and the Jewish Struggle with Modernity. Boston: Beacon Press.

Douglas, Susan 1994 The Media on Thin Ice. The Progressive 58(3):12.

Duffy, Martha 1994a With Blades Drawn. Time, February 21, pp. 53-58.

-1994b End of the Winter's Tale. Time, March 7, pp. 62-65.

Foucault, Michel 1982 Afterword: The Subject and Power. Pp. 208-226. In Michel Foucault: Beyond Structuralism and Hermeneutics, Hubert Dreyfus and Paul Rabinow, eds., pp. 208-226, Chicago: University of Chicago Press.

Frankenberg, Ruth 1993 White Women, Race Matters: The Social Construction of Whiteness. Minneapolis: University of Minnesota Press.

Garber, Marjorie 1992 The Occidental Tourist: M. Butterfly and the Scandal of Transvestism. In Nationalisms \& Sexualities, Mary Russo Andrew Parker Doris Sommer and Patricia Yaeger, eds., pp. 121-146, New York: Routledge.

Gramsci, Antonio 1971 Selections from the Prison Notebooks. New York: International Publishers.

Greenfield, Meg 1994 Moral Icecapades. Newsweek, February 28, 1994, p. 70.

Grimes, William 1994 Fairy Tales on Ice, and horror Stories Off It. New York Times, Jan. 16, Week In Review, p. 1. 
Hall, Stuart 1988 The Toad in the Garden: Thatcherism among the Theorists. In Marxism and the Interpretation of Culture, Cary Nelson and Lawrence Grossberg, eds., pp. 35-73. Urbana: University of Illinois Press.

Henry III, William A. 1994. Finally, the Games. Time, February 21, pp. 50-51. Hirsch, E.D. Jr., Joseph F. Kett and James Trefil 1988 The Dictionary of Cultural Literacy. Boston: Houghton Mifflin Company.

Hill, Jane H. 1994a Junk Spanish, Anglo Identity, and the Forces of Desire. Presented at the Symposium "Hispanic Language and Social Identity," Albuquerque, N.M., Feb. 10-12, 1994.

-1994b The Incorporative Power of Whiteness. Presented at the American Ethnological Society, Santa Monica, CA. April 16, 1994.

hooks, bell 1990 Yearning: Race, Gender and Cultural Politics. Boston: South End Press.

Horsman, Reginald 1981 Race and Manifest Destiny: The Origins of American Racial Anglo-Saxonism. Cambridge: Harvard University Press.

Janofsky, Michael 1991 Wearing the Crown, without the Glitz. New York Times, February 18, p. 31.

-1994 Harding Strikes a Plea Bargain and Won't Skate for World Title. New York Times, March 17, p. 1.

Kapferer, Bruce 1988 Legends of People, Myths of State: Violence, Intolerance, and Political Culture in Sri Lanka and Australia. Washington: Smithsonian Institution Press.

Kirkpatrick, Curry 1994 The Saga that Knew No Bounds. Newsweek March 7, pp. 58-59.

Klein, Joe $1994 \mathrm{Hi}$, I'm Joe and I Love Tonya Too Much. Newsweek, February 14, p. 57.

Krause, Elizabeth L 1994 Forward vs. Reverse Gear: The Politics of Proliferation and Resistance in the Italian Fascist State. Journal of Historical Sociology 7 (3).

Levine, Judith 1994 The Heart of Whiteness: Dismantling the Master's House. Village Voice, Literary Supplement.

Lieberson, Stanley 1985 Unhyphenated Whites in the United States. Ethnic and Racial Studies 8 (1):159-180.

Lipsyte, Robert 1995 The Emasculation of Sports. New York Times Magazine, April 2, 1995, pp. 51-56.

Longman, Jere 1993 Skating on Life's Thin Ice with Hard-Luck Harding. New York Times, October 26, 1993, p. 58.

Mauss, Marcel 1979 [1950] Sociology and Psychology. London: Routledge \& Kegan Paul.

McWhiney, Grady 1988 Cracker Culture: Celtic Ways in the Old South. Tuscaloosa: The University of Alabama Press.

Mouffe, Chantal 1981 Hegemony and Ideology in Gramsci. In Culture, Ideology and Social Process, Graham Martin, Tony Bennett, Colin Mercer and Janet Woollacott, eds., pp. 219-234. Worcester: The Open University Press.

National Review (n.a.) 1994 The Sporting Life. National Review 46(3):20-21, February 21, 1994.

Newman, Gerald 1987 The Rise of English Nationalism: A Cultural History 17401830. New York: St. Martin's Press.

New York Times (n.a.) 1991 Harding Stuns with Triple Axel. February 17, p. 23. 
Orlean, Susan 1994 Figures in a Mall. The New Yorker, February 21, pp. 48-63.

Parker, Andrew, Mary Russo, Doris Sommer and Patricia Yaeger 1992 Introduction. In Nationalisms \& Sexualities, Mary Russo, Andrew Parker, Doris Sommer and Patricia Yaeger, eds., pp. 1-18. New York: Routledge.

Parmentier, Richard J. 1994 Signs in Society: Studies in Semiotic Anthropology. Bloomington: Indiana University Press.

Pollitt, Katha 1994 Subject to Debate. The Nation, March 7, 258(9):297.

Puijk, Roel 1994 Norwegian Culture and the Olympic Ceremonies. Paper Presented at the Society for Applied Anthropology, in the session, Heritage Tourism and the Global Village. April 14, 1994, Cancun, Mexico.

Reid, T.R. 1994 America's Soul on Ice; Overseas, Tonya's Flaws Represent her Country's. The Washington Post, February 6, p. C1.

Robertiello, Richard C. and Diana Hoguet 1987 The WASP Mystique, New York: Donald I. Fine Inc.

Roediger, David R. 1991 The Wages of Whiteness: Race and the Making of the American Working Class. London: Verso.

Roseberry, William 1994 Hegemony and the Language of Contention. In Everyday Forms of State Formation: Revolution and the Negotiation of Rule in Modern Mexico, G. Joseph and Daniel Nugent, eds., pp. 355-366. Durham: Duke University Press.

Rounds, Kate 1994 Ice Follies: Reflections on a Sport. Ms. 4(6 May/June): 26-33.

Saxton, Alexander 1990 The Rise and Fall of the White Republic: Class Politics and Mass Culture in Nineteenth-Century America. London: Verso.

Schneider, David M. 1969 Kinship, Nationality and Religion in American Culture: Toward a Definition of Kinship. Proceedings 1969 Annual Spring Meeting of the American Ethnol. Society.

Scott, Joan W. 1986 Gender: A Useful Category for Historical Analysis. The American Historical Review 91 (5):1053-1075.

Silverblatt, Irene 1991 Interpreting Women in States: New Feminist Ethnohistories. In Gender at the Crossroads of Knowledge: Feminist Anthropology in the Postmodern Era, Micaela di Leonardo, ed., pp. 140-171. Berkeley: University of California Press.

Smolowe, Jill 1994 Tarnished Victory. Time, January 24, pp. 50-57.

Szwed, John F. 1975 Race and the Embodiment of Culture. Ethnicity 2:19-33.

Therborn, Göran 1980 The Ideology of Power and the Power of Ideology. London: Verso Editions.

Touraine, Alain 1977 The Self-Production of Society. Chicago: University of Chicago Press.

Turner, Victor 1974 Dramas, Fields and Metaphors: Symbolic Action in Human Society, Ithaca: Cornell University Press.

van Dijk, Teun A. 1993 Elite Discourse and Racism, London: Sage Publications. Williams, Brackette 1989 A Class Act: Anthropology and the Race to Nation Across Ethnic Terrain. Annual Review of Anthropology 18:401-444.

-1991 Stains on My Name, War in My Veins: Guyana and the Politics of Cultural Struggle. Durham: Duke University Press.

-1993 The Impact of the Precepts of Nationalism on the Concept of Culture: Making Grasshoppers of Naked Apes. Cultural Critique (24/Spring):143-191. 
Wolf, Eric R. 1982 Europe and the People Without History, Berkeley: University of California Press.

Vecsey, George 1994a Boston Fans Welcome Home Their Nancy. New York Times, Feb. 4.

-1994b Harding's Guilty Plea Anticlimactic. New York Times, March 17.

Yuval-Davis, Nira 1989 Introduction. In Woman - Nation - State, Nira Yuval-Davis and Floya Anthias, eds., pp. 1-15. London: MacMillan. 